\title{
PRIMENA EUROGITES STANDARDA ZA PROCENU KVALITETA USLUGA U AGROTURIZMU
}

\author{
Marko D. Petrovićl ${ }^{\star}$, Snježana Gagić ${ }^{2}$, Željko Bjeljac ${ }^{1}$, Dunja Demirović ${ }^{3}$, Karolina Simat ${ }^{3}$ \\ ${ }^{1}$ Geografski institut „Jovan Cvijicic SANU, Đure Jakšića 9, Beograd, Srbija \\ ${ }^{2}$ Visoka škola za menadžment i poslovne komunikacije, Mitropolita Stratimirovića 110, Sremski Karlovci, Srbija \\ ${ }^{3}$ Departman za geografiju, turizam i hotelijerstvo, Prirodno-matematički fakultet, \\ Univerzitet u Novom Sadu, Trg Dositeja Obradovića 3, Novi Sad, Srbija
}

\section{Apstrakt:}

U radu su predstavljene pojmovne odrednice agroturizma kroz povezanost s kriterijumima kvaliteta usluga. Na osnovu primera dobrih praksi i iskustava iz evropskih država, Evropska federacija za farmerski (agroturizam) i seoski turizam (skr. EuroGites) je uspostavila jedinstvene standarde za procenu kvaliteta smeštajnih jedinica u ruralnom prostoru. Kriterijumi uspostavljenih standarda su grupisani u pet klastera (blokova): opremljenost, okruženje, usluge u smeštajnoj jednici i njenoj okolini, nematerijalni aspekti i bezbednost. Cilj rada je da se pomoću EuroGites metodološkog instrumenta izvrši poređenje između ispunjenih minimalnih uslova za međunarodno i domaće tržište, kroz procenu kvaliteta segmenata agroturizma u izabranim seoskim naseljima na teritoriji AP Vojvodine (Srbija). Osnovna hipoteza rada polazi od procene da je kvalitet agroturizma u Vojvodini merljiv pomoću poređenja ispunjenosti EuroGites kriterijuma na domaćem i na međunarodnom nivou. Dobijeni rezultati pokazali su da su tri podhipoteze potvrđene, a dve opovrgnute. Nalazi istraživanja predstavljaju korisno sredstvo za dobijanje informacija o brojnim segmentima kvaliteta u agroturizmu, i sa neznatnim modifikacijama, mogu se koristiti u najrazličitijim prostorima istraživanja kvaliteta usluga.
\end{abstract}

\section{Ključne reči:}

agroturizam,

EuroGites,

klasteri kriterijuma,

segmenti kvaliteta,

AP Vojvodina (Srbija).

\section{Napomena:}

Rad je podržan od strane republičkog projekta III 47007, finansiranog od strane Ministarstva prosvete, nauke i tehnološkog razvoja Republike Srbije.

\section{UVOD}

Uticaj globalnih procesa na razvoj privrede ogleda se i u intenzitetu i pravcu turističkih tokova, pa tako i u razvoju posebnih vidova turizma (turizma selektivnih interesovanja). U savremenom proučavanju razvoja međunarodnih turističkih trendova, ruralni turizam se javlja kao njegov veoma značajan i rastući segment. U okviru ruralnog turizma, važan deo čine aktivnosti koje se mogu definisati kao agroturističke aktivnosti. Iako izgleda jednostavno definisati termin „agroturizam” (eng. Agritourism) ili „turizam na imanju, farmi, domaćinstvu ili gazdinstvu" (eng. Farm tourism / Farm-stay tourism) kao „turizam koji se odvija u agrarnom prostoru", ova definicija ne uključuje složenost aktivnosti i raznovrsne oblike i značenja koji su razvijeni u različitim zemljama. Nikerson i saradnici (Nickerson et $a l, 2001$ ) navode da je ruralni prostor osnovni resurs za razvoj agroturizma i da se ova turistička aktivnost oslanja na potrebu gradskih stanovnika za mirom i prostorom za sportsku rekreaciju na otvorenom. Uz to, autori napominju da su boravak na seoskim domaćinstvima i ruralni krajolik nezaobilazni pri ovoj turističkoj aktivnosti. Nilson (Nilsson, 2002) i Petrović (2013; 2014), u svojim radovima o agroturizmu, definišu ovaj vid turizma kao osnovni segment ruralnog turizma. Prema Nilsonu, ruralni turizam se zasniva na ruralnom okruženju uopšte, dok se agroturizam isključivo zasniva na poljoprivrednom dobru i proizvođaču. Međutim, agroturizam se ipak konvencionalnije koristi za pojmove koji se odnose na turističke proizvode i usluge koji su direktno vezani za poljoprivrednu (agrarnu) sredinu, poljoprivredne proizvode i za vidove boravka na seoskim domaćinstvima. Takve aktivnosti uključuju: boravak u takvoj sredini (bilo u privatnoj smeštajnoj jedinici ili u vidu kampovanja), obrazovne posete, rekreativne aktivnosti ili prodaju poljoprivrednih proizvoda i proizvoda ručne, odnosno domaće radinosti (Sznajder et al, 2009). 
Ako se prihvati koncept da agroturistički proizvod obuhavata isključivo skup turističkih usluga i aktivnosti na seoskim domaćinstvima i objektima domaće radinosti, može se konkretizovano analizirati kvalitet takvog proizvoda. Upravo takva analiza će biti predmet istraživanja ovog rada, što je bio predmet istraživanja brojnih teoretičara prethodnih godina (Hall \& Richards, 2000; Reichel et al, 2000; Sirgy \& Cornwell, 2001; Nickerson et al, 2001; Sirgy, 2001; Hall et al, 2003; Adams, 2008; George et al, 2009; Sznajder et al, 2009).

S obzirom na poteškoće pri kreiranju i implementaciji jedinstvenih standarda kvaliteta u ruralnim vidovima turizma, brojni teoretičari su nalazili rešenja da uspostave standardizaciju i u ovom segmentu turističke privrede. Nalaženi su načini da se proceni kvalitet smeštajnih jedinica, koje su deo ponude ruralnih vidova turizma, kakav je i agroturizam. Kako Roberts i Hol (Roberts \& Hall, 2001) navode, izuzetno je komplikovano uporediti kvalitet objekta, odnosno proizvoda i usluga koje nudi neko seosko domaćinstvo ili objekat domaće radinosti, sa uslugama koje nudi hotel, vila ili rizort. Tim povodom, Evropska federacija farmerskog (agroturizma) i seoskog turizma (eng. European Federation of Farm and Village Tourism), poznatija je pod akronimom EuroGites, imala je za cilj da privuče što veći broj evropskih zemalja za priključenje ovoj federaciji, kako bi došlo do umrežavanja i poboljšanja usluga u ruralnom turizmu zemalja članica. Godine 2014., federacija je brojala 35 profesionalnih organizacija iz 28 evropskih zemalja (uključujući i Srbiju), koje su nudile izbor od oko 100.000 objekata za smeštaj turista u ruralnim prostorima. Ponudu najčešće čine usluge noćenja s doručkom (BB) ili samo najma (NA) smeštajnih jedinica, zavisno od vrste smeštaja. Zahvaljujući objedinjenoj ponudi na nivou kontinenta, EuroGites danas čini važnu bazu ponude ugostiteljskih kapaciteta u ruralnim sredinama zemalja članica.

$\mathrm{Na}$ osnovu primera dobrih praksi i iskustava iz evropskih država, EuroGites federacija je uspostavila jedinstvene standarde za procenu kvaliteta smeštajnih jedinica u ruralnom prostoru (eng. EuroGites Quality Assessment Standards - Rural Accommodation) za sve države članice. Uspostavljeni standardi kvaliteta ove federacije predstavljaju rezultat dogovora postignutog tokom Generalne skupštine federacije 2005. godine, a koji su podržani od strane svih tadašnjih članica (http://www.eurogites.org). Kriterijumi uspostavljenih standarda su grupisani u pet klastera (blokova): opremljenost (19 kriterijuma), okruženje (devet kriterijuma), usluge u smeštajnoj jednici i njenoj okolini $(<15$ $\mathrm{km}$ ) (devet kriterijuma), nematerijalni aspekti (ambijent, privatnost, pažnja o detaljima...) (sedam kriterijuma) i bezbednost (devet kriterijuma).

Klasteri su definisani na osnovu rezultata međunarodnog istraživanja stavova posetilaca o kvalitetu ruralnih vidova turizma, radi pronalaženja i definisanja njihovih potreba. Istraživanje je zatim ponovljeno u periodu 20092010. godine među ispitanicima iz 40 evropskih zemalja. Segmenti klastera su podeljeni u dve kolone, tačnije svaka stavka ovog dokumenta ima kriterijum koji se odnosi na domaće i kriterijum koji se odnosi na međunarodno tržište. Da bi obezbedili jasne smernice za EuroGites jedinstvene standarde za procenu kvaliteta smeštajnih kapaciteta u ruralnom turizmu, 2008. godine je pokrenut projekat Qualitool, u okviru kojeg su razvijene alatke za uspostavljanje standarda kvaliteta. Ovaj projekat je finansijski podržan od strane EU programa „Leonardo da Vinči” (eng. EU - Leonardo da Vinci programme) i čine ga tri etape:

1. kvalitet samoprovere: elektronska aplikacija za procenu usklađenosti kapaciteta ruralnog turizma sa EuroGites minimalnim međunarodnim standardima kvaliteta,

2. inspekcija za korisnike: dokument koji objašnjava kako da se razume i proceni usaglašenost kapaciteta sa standardnim kriterijumima i

3. virtuelni trening modul: elektronska aplikacija gde su standardni kriterijumi objašnjeni kroz primere sa fotografijama i snimcima smeštajnih jedinica ruralnog turizma u nekoliko zemalja (http://quality.eurogites.org).

Nakon rednog broja i opisa, EuroGites klasteri su podeljeni u dve kolone, tačnije svaka stavka ovog dokumenta ima kriterijum koji se odnosi na minimalne uslove za domaće tržište i kriterijum koji definiše minimalne uslove za međunarodno tržište. Iako su umnogome istovetni, uslovi za međunarodno tržište su znatno rigorozniji i zahtevniji po pitanju većine navedenih klasterskih kriterijuma. Ispitanici su odgovarali sa odgovorima „da” (ispunjavam zadate uslove) ili "ne” (ne ispunjavam zadate uslove) na oba kriterijuma.

Klaster 1 (opremljenost agroturističkih smeštajnih jedinica) broji 19 kriterijuma i tiče se sadržaja agroturističkih smeštajnih jedinica, gde su glavni kriterijumi fokusirani na enterijerske segmente, po pitanju tehničko-tehnoloških, sanitarno-higijenskih, organizacionih i prostornih aspekata smeštajnih jedinica. Opremljenost u ovom slučaju podrazumeva aspekte od stila gradnje objekata, dekorisanja i očuvanosti objekata, preko veličine, dimenzija i sadržaja u sobama, do zastupljenosti i opremljenosti toaleta, grejanja i klimatizacije svih prostorija u kojim borave gosti.

Klaster 2 (okruženje agroturističkih smeštajnih jedinica) broji devet kriterijuma i odnosi se na bližu i dalju okolinu agroturističke smeštajne jedinice. Fokus je stavljen na spoljašnjim uticajima (prirodnim i antropogenim), nivou očuvanosti okolnog ruralnog okruženja, s akcentom na kulturnom nasleđu i očuvanim prirodnim potencijalima u okolini. Autori standarda napominju i da je u ovom klasteru važno isticanje društvene odgovornosti i odgovornosti prema lokalnom okruženju i životnoj sredini od strane domaćina, kao i neophodnost savetovanja sa lokalnim zainteresovanim učesnicima (drugi domaći proizvođači hrane, pića i napitaka, trgovci, zanatlije, turistički vodiči i sl.) u agroturizmu.

Klaster 3 (usluge u agroturističkoj smeštajnoj jedinici i njenoj okolini do $15 \mathrm{~km}$ ) uključuje devet kriterijuma koji obuhvataju aspekte vezane za održavanje soba i prostorija za pružanje usluga ishrane gostiju, kao i rekreativne mogućnosti i prilaz do same agroturističke smeštajne jedinice. U okviru ovog klastera naglašen je segment informisanosti gostiju o generalnim informacijama iz bližeg i daljeg okruženja, kao i spisak informacija i instrukcija za goste unutar smeštajne jedinice.

Klaster 4 (posvećenost gostu, privatnost i ambijent u agroturističkoj smeštajnoj jedinici) broji sedam kriterijuma i tiče se komunikativnih i psiholoških aspekata na relaciji odnosa domaćina prema gostima. U ovom bloku 
kriterijuma naznačena je važnost komunikativnih veština domaćina, iskazivanje prijatne dobrodošlice, dostupnost domaćina tokom boravka gostiju, kao i poznavanje ciljnih, stranih jezika iz zemalja odakle dolazi većina turista. U protivnom, preporučuje se dobro znanje engleskog jezika, kao dominantnog svetskog jezika.

Klaster 5 (bezbednost u agroturističkim smeštajnim jedinicama) broji devet kriterijuma koji se baziraju na sigurnosnim uslovima kroz koje objekat treba proći. Među tim kriterijumuma ističu se: tehnički, zdravstveno-higijenski, pravni, rezervacioni i drugi.

Svi navedeni standardi u okviru ovih pet klastera se izrazito preporučuju za sve članice federacije EuroGites, ali nisu obavezni. U svakom slučaju, članice federacije treba da rade na tome da vremenom usaglase što više kriterijuma s zadatim smernicama i sinhronizuje sa ostalim članicama. Takođe, tokom marketinškog predstavljanja, svaka smeštajna jedinica se treba usaglasiti s uslovima korišćenja naziva brenda EuroGites. Svaki objekat koji zvanično popuni pravila aplikacije i dostavi podatke federaciji, pojedinačno odgovara za ispravnost popunjenih stavki koje su označene (na nacionalnom i međunarodnom nivou). Pri tom, EuroGites ima pravo nenajavljene kontrole i provere svih zadatih kriterijuma. Dopuštena odstupanja od zadatih kriterijuma su moguća do $25 \%$ za sve kriterijuma koje imaju skale (14), dok se u slučaju apsolutnih veličina (npr. veličina sobe, čistoća, osvetljenje i sl.), odstupanja ne tolerišu. U svakoj od tačaka kriterijuma mora se ispoštovati apsolutni minimum, jer u protivnom ako nije zadovoljen, automatski eliminiše taj objekat iz dalje procedure. Stoga, dostavljeni upitnici, treba da u potpunosti odgovore na sve zatražene kriterijume.

Poslednjih godina, EuroGites standarde su objasnili i primenili mnogi autori u savremenim naučnim referencama (Buselić et al, 2008; Spanos \& Doman, 2011; Stoian, 2011a; 2011b; Gherasim, 2012; Caprarescu et al, 2013). Konstatovano je da su ovi standardi izuzetno efikasan instrument za analiziranje velikog broja aspekata kvaliteta ponude i da su kao takvi vrlo primenljivi u najrazličitijim ruralnim prostorima, što je već urađeno na primeru $\mathrm{Ru}$ munije, Hrvatske, Grčke i sl. S obzirom na to da se ovako uspostavljeni standardi kvaliteta efikasno primenjuju u velikom broju evropskih zemalja, došlo se do pretpostavke da se može svrsishodno koristiti i za istraživanje stanja agroturističkih smeštajnih jednica (seoska turistička domaćinstva i objekti domaće radinosti) u AP Vojvodini (i u čitavoj Srbiji). U diskusiji će biti izneseni konkretni odgovori, odnosno rezultati njihovog testiranja na osnovu pilot istraživanja u analiziranim vojvođanskim selima.

\section{REZULTATI I DISKUSIJA}

Tokom istraživanja za potrebe pisanja ovog rada, ciljne grupe su već bile unapred utvrđene i definisane. Cilj je bio da se u 17 turistički najreprezentativnijih (najspremnijih) seoskih naselja u AP Vojvodini ${ }^{1}$ ispita kvalitet brojnih segmenata agroturizma. U prvoj fazi istraživanja anketirani

1 Izbor seoskih naselja izvršen je na osnovu izabranih 17 sela u okviru projekta „Bogatstvo različitosti”, Dunavskog turističkog klastera „Istar 21”, a podržanog od strane Vlade AP Vojvodine. Više informacija na sajtu: http://www.istar21.rs/projekti/bogatstvo_razlicitosti/3013-projekat-bogatstvo-razlicitosti.html su stanovnici izabranih vojvođanskih sela, tokom oktobra, novembra i decembra 2013. godine. U drugoj fazi istraživanja anketiranje je obavljeno tokom međunarodnih sajmova turizma u Beogradu i Novom Sadu (februar i april 2014. godine), gde su ponovo bili anketirani stanovnici izabranih vojvođanskih sela. Osnovni cilj kvantitativnog istraživanja bilo je utvrđivanje postojećeg stanja u agroturizmu Vojvodine na osnovu izabranih seoskih naselja. Upitnik sastavljen po uzoru na originalne EuroGites standarde bio je namenjen direktnim pružaocima usluga u agroturizmu (vlasnicima, njihovim porodicama i zaposlenima u agroturističkim smeštajnim jedinicama). Od ukupno planiranih 100 anketnih upitnika, vraćeno je 69 pravilno popunjenih, pa će rezultati iz tih upitnika biti dalje analizirani ( $\mathrm{N}=69)$. Prema teoretičaru Babiju (Babbie, 1986), stopa odaziva među ispitanicima koja je na nivou od 70\% ili iznad tog udela, smatra se veoma dobrim pokazateljem prihvaćenosti merne skale. U ovom slučaju stopa odaziva nije značajno ispod preporučene mere od $70 \%$, pa se može tolerisati.

Osnovna hipoteza rada glasi (H1): Kvalitet agroturizma u Vojvodini je merljiv pomoću poređenja ispunjenosti uslova na domaćem i na međunarodnom nivou. Ova hipoteza je oformljena na osnovu pretpostavki dobijenih rezultata pomoću EuroGites metodologije, gde će se analizirati ispunjenost uslova po pet zadatih kriterijuma, na međunarodnom i na domaćem nivou. Hipoteza će u rezultatima rada biti potvrđena ili opovrgnuta primenom EuroGites metodoloških instrumenata. Ova hipoteza uključuje pet pothipoteza:

H1a: Opremljenost agroturističkih smeštajnih jedinica u većoj meri zadovoljava kriterijume prema domaćim, a u manjoj meri prema međunarodnim standardima.

H1b: Okruženje agroturističkih smeštajnih jedinica u istoj meri zadovoljava kriterijume prema domaćim i prema međunarodnim standardima.

H1c: Usluge u agroturističkim smeštajnim jedinicama u većoj meri zadovoljavaju kriterijume prema domaćim, a u manjoj meri prema međunarodnim standardima.

H1d: Posvećenost gostu, privatnost i ambijent u agroturističkim smeštajnim jedinicama $u$ istoj meri zadovolja kriterijume prema domaćim i prema međunarodnim standardima.

H1e: Bezbednost u agroturističkim smeštajnim jedinicama u većoj meri zadovoljava kriterijume prema domaćim, a u manjoj meri prema međunarodnim standardima.

Segmenti korišćenih EuroGites standarda kvaliteta se odnose na pet blokova kriterijuma, odnosno uslova. Broj ispitanika čije smeštajne jedinice zadovoljavaju kriterijume na nacionalnom i međunarodnom nivou biće prikazani u ovom poglavlju rada. Svaka kategorija u okviru pet blokova biće vrednovana u odnosu na broj potvrdnih odgovora koje je dobila prema zadatom kriterijumu (domaćem ili međunarodnom). Vrednosti će biti kvalitativno interpretirane na osnovu numeričkih pokazatelja i glasiće:

1. Veoma visoka vrednost $(\mathrm{N}=\geq 60)$,

2. Visoka vrednost $(\mathrm{N}=45-59)$,

3. Srednja vrednost $(\mathrm{N}=30-44)$,

4. Niska vrednost $(\mathrm{N}=15-29) \mathrm{i}$

5. Veoma niska vrednost $(\mathrm{N} \leq 14)$. 


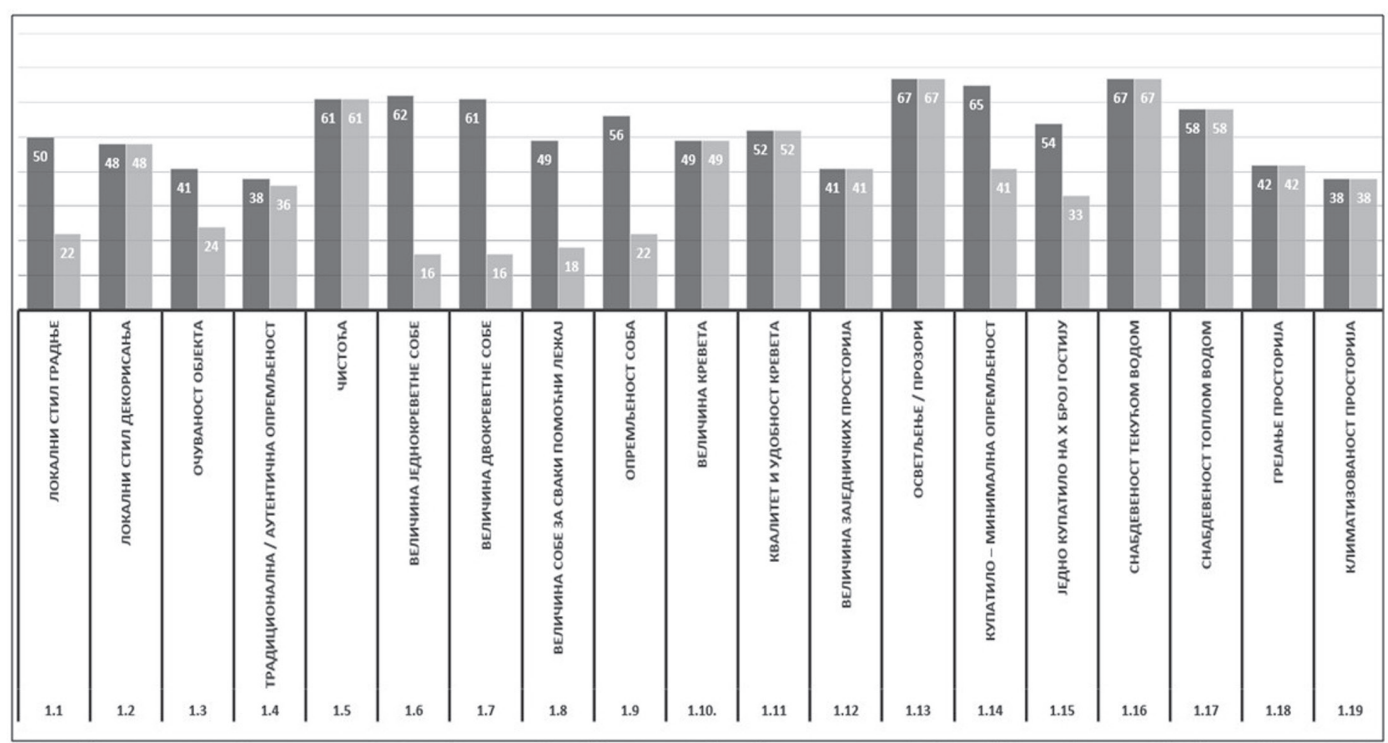

Grafikon 1. Prikaz rezultata ispunjenih standarda prema kriterijumima Bloka $1(\mathrm{~N}=69)$

Legenda: tamnosivi stubovi - broj ispitanika koji ispunjava uslove za domaće tržište / svetlosivi stubovi - broj ispitanika koji ispunjava uslove i za međunarodno tržište

U Grafikonu 1. prikazani su rezultati Bloka 1, na osnovu kojih se može zaključiti da najveći broj ispitanika $(\mathrm{N}=67)$, po oba kriterijuma (domaći i međunarodni), ispunjava uslove kategorija „osvetljenje / prozori u prostorijama” $\mathrm{i}$ „snabdevenost tekućom vodom". Ovo su ujedno i osnovni uslovi za koje je i bilo očekivanje da se moraju ispuniti, jer su i kriterijumi na oba nivoa istovetni, tačnije obavezni. S druge strane, dvoje ispitanika je obeležilo negativan odgovor, pa se veruje da su njihovi objekti još u procesu adaptacije (spoljnih renoviranja ili enterijerskih izmena). Apsolutna većina ispitanika zadovoljava izuzetno visoke vrednosti $(\mathrm{N} \geq 60)$, jer ispunjava kriterijume za domaće tržište u kategorijama „minimalni uslovi za opremljenost kupatila” $(\mathrm{N}=65)$, „veličina jednokrevetne sobe” (N=62), „veličina dvokrevetne sobe” (N=61) i „čistoća” $(\mathrm{N}=61)$. U okviru ovih kategorija postoje jasni kriterijumi koji su propisani nacionalnim ili lokalnim pravnim aktima. Interesantno je spomenuti da kategorija „veličina kreveta” ( $N=49)$, prema EuroGites standardima za međunarodno tržište je potpuno jednaka propisima kao i u našem zakonodavstvu.

$S$ druge strane, treba napomenuti da izuzetno mali udeo potvrdnih odgovora je prema međunarodnim propisanim standardima, odnosno pokazuju niske vrednosti $(\mathrm{N} \leq 29)$. Takve vrednosti su primetne u kategorijama: „lokalni stil gradnje” ( $\mathrm{N}=22)$, ,očuvanost objekta” $(\mathrm{N}=24)$, ,opremljenost soba” $(\mathrm{N}=22)$, „veličina jednokrevetne sobe” $(\mathrm{N}=16)$, „veličina dvokrevetne sobe” ( $\mathrm{N}=16) \mathrm{i}$ „veličina sobe za svaki pomoćni ležaj" (N=18). Svi ostali pokazatelji su u rasponu srednjih ili visokih vrednosti $(\mathrm{N}=30-59)$, pa se o njima neće dalje diskutovati. Dobijeni rezultati delimično potvrđuju pothipotezu H1a da opremljenost agroturističkih smeštajnih jedinica u većoj meri zadovolja kriterijume prema domaćim, a u manjoj meri prema međunarodnim standardima, s obzirom da je u polovičnom broju slučajeva (10 od 19 slučajeva) ta hipoteza opovrgnuta.

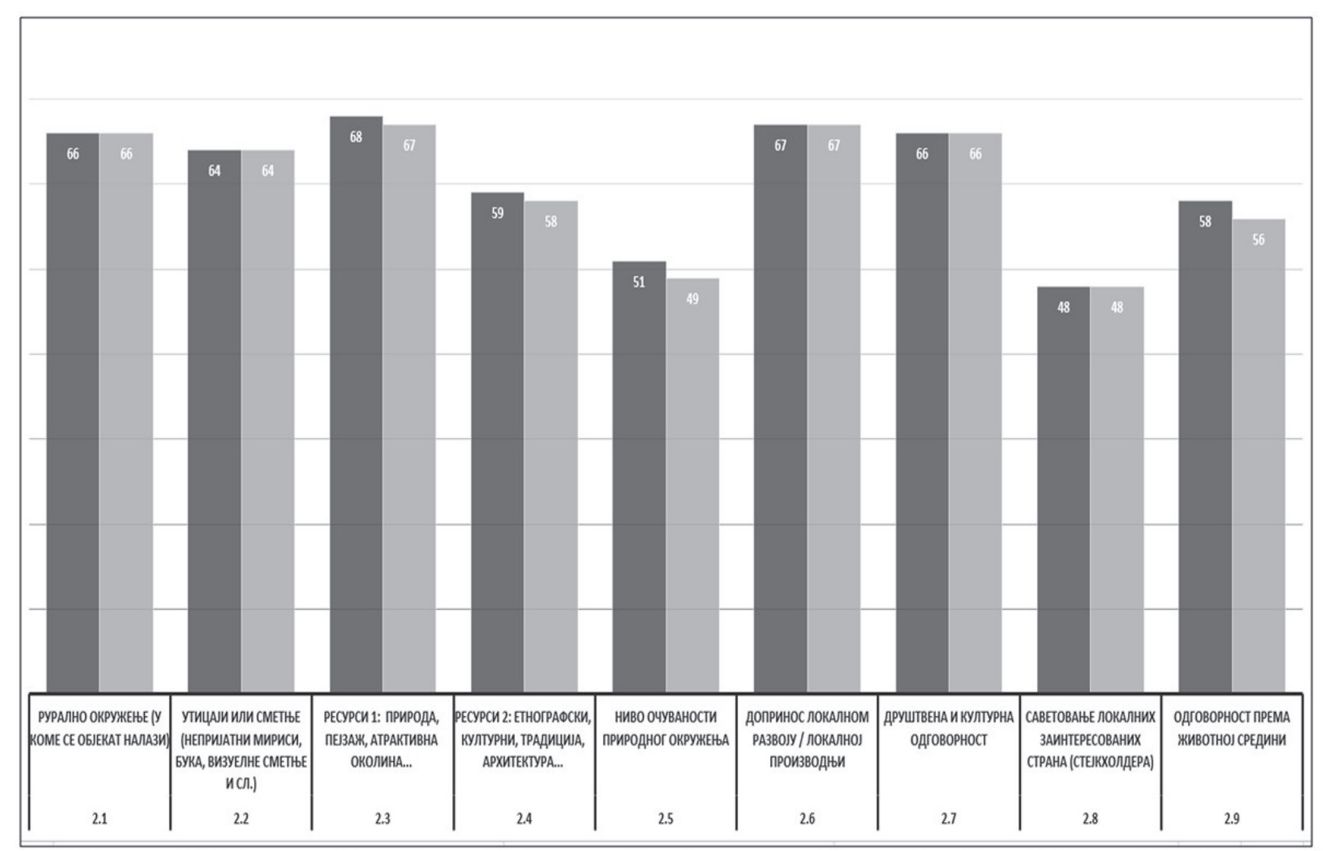

Grafikon 2. Prikaz rezultata ispunjenih standarda prema kriterijumima Bloka 2 (N=69)

Legenda: tamnosivi stubovi - broj ispitanika koji ispunjava uslove za domaće tržište / svetlosivi stubovi - broj ispitanika koji ispunjava uslove i za međunarodno tržište 
Prikazani rezultati Bloka 2 (Graf. 2) pokazuju da se veoma visoke vrednosti ( $\mathrm{N} \geq 60$ ), po oba kriterijuma (domaći i međunarodni), mogu primetiti u kategorijama „doprinos lokalnom razvoju / lokalnoj proizvodnji” (N=67), „društvena i kulturna odgovornost” ( $\mathrm{N}=66)$, „ruralno okruženje u kome se objekat nalazi” ( $\mathrm{N}=66)$ i potencijalni "uticaji ili smetnje” $(\mathrm{N}=64)$, poput buke, vizuelnih smetnji, neprijatnih mirisa i sl. Takav nivo vrednosti se može zapaziti i u kategoriji „resursi 1: priroda, pejzaž, atraktivna okolina", ali postoji blaga razlike između uslova za domaće tržište $(\mathrm{N}=68)$ i uslova za međunarodno tržište $(\mathrm{N}=67)$. Iste ili slične vrednosti po oba kriterijuma su očekivane, s obzirom na slične ili identične uslove koji se nameću u EuroGites standardima na oba nivoa.

$S$ druge strane, najniže vrednosti u ovom bloku se primećuju u kategorijama „nivo očuvanosti prirodnog okruženja" ( $\mathrm{N}=49$ ), po međunarodnim kriterijumima i prema oba kriterijuma u kategoriji „savetovanje lokalnih zainteresovanih strana" $(\mathrm{N}=48)$. Za razliku od prethodnog grafikona, najniže dobijene vrednosti u ovom bloku se po opštoj klasifikaciji kategorišu kao visoke vrednosti ( $\mathrm{N}=45-59)$. Ovakvi rezultati nagoveštavaju da je specifičnost u prvom slučaju („očuvanost prirodnog okruženja”), gde se očekuju standardi koji su zastupljeni u većini zemalja članica EU (npr. visoka ekološka svest, organizovano upravljanje otpadom, visokoefikasne komunalne službe, reciklažni centri i sl.), a koji još uvek nisu pristni u AP Vojvodini (Srbiji). Takođe, pretpostavka je da je kod kategorije „savetovanje lokalnih zainteresovanih strana" dobijena nešto niže vrednost, jer izvestan broj ispitanika možda nije najbolje razumeo zadato pitanje, pa ubuduće treba razjasniti i obrazložiti značenje pomenute konstatacije. Dobijeni rezultati delimično potvrđuju pothipotezu H1b da okruženje agroturističkih smeštajnih jedinica $\mathrm{u}$ istoj meri zadovoljavaju kriterijume i prema domaćim i prema međunarodnim standardima, s obzirom da je u polovičnom broju slučajeva (pet od devet slučajeva) ta hipoteza opovrgnuta.
Grafikon 3. ilustruje rezultate Bloka 3, gde se mogu uočiti najveći broj maksimalnih vrednosti (N=69) u odnosu na ostala četiri bloka. Potrebno je istaći da čak pet od devet ponuđenih kategorija imaju takve vrednosti, a to su kategorije: „održavanje soba”, „obezbeđeni obroci u smeštajnoj jedinici”, „izbor rekreativnih mogućnosti u okviru smeštajne jedinice”, „izbor rekreativnih mogućnosti u okolini” i „objekti za doručak”. U svim kategorijama, osim poslednje („objekti za doručak”), vrednosti su maksimalne po oba kriterijuma (domaći i međunarodni), odnosno odgovor ispitanika je bio potvrdan u oba slučaja. Razlog ovakve pojave se objašnjava u identičnim kriterijumima, gde se domaći izjednačavaju sa međunarodnim uslovima. Veoma visoka vrednost se primećuje i kod kategorije „prilaz objektu / putokazi” ( $\mathrm{N}=67)$, ali samo prema uslovima za domaće tržište, s obzirom da kriterijum nije posebno izričit (osnovni, nestandardizovani prilazi i putokazi).

Suprotno ovim podacima, kod nekih kategorija su uočljive niske vrednosti $(\mathrm{N}=15-29)$ prema uslovima za međunarodno tržište, a to su kategorije: ,informacije za turiste” $(\mathrm{N}=22)$ i „informacije o smeštaju” $(\mathrm{N}=19)$. S druge strane, vrednosti prema uslovima za domaće tržište su veoma visoke kod istih kategorija: „informacije za turiste” $(\mathrm{N}=61)$ $\mathrm{i}$,informacije o smeštaju” ( $\mathrm{N}=62)$, s obzirom da u apsolutnoj većini slučaja preovlađuju informacije na srpskom jeziku, odnosno informacije su namenjene gotovo isključivo domaćim gostima. Razlog ovakvih rezultata govori u prilog činjenici da pružaoci usluga u agroturizmu AP Vojvodine još uvek, u većoj meri, nisu prilagodili svoje objekte potrebama i zahtevima inostranih gostiju, pa u tom segmentu treba još dosta unaprediti usluge. Dobijeni rezultati delimično potvrđuju pothipotezu H1c da usluge u agroturističkim smeštajnim jedinicama u većoj meri zadovoljaju kriterijume prema domaćim, a u manjoj meri prema međunarodnim standardima, s obzirom da je u polovičnom broju slučajeva (pet od devet slučajeva) ta hipoteza opovrgnuta.

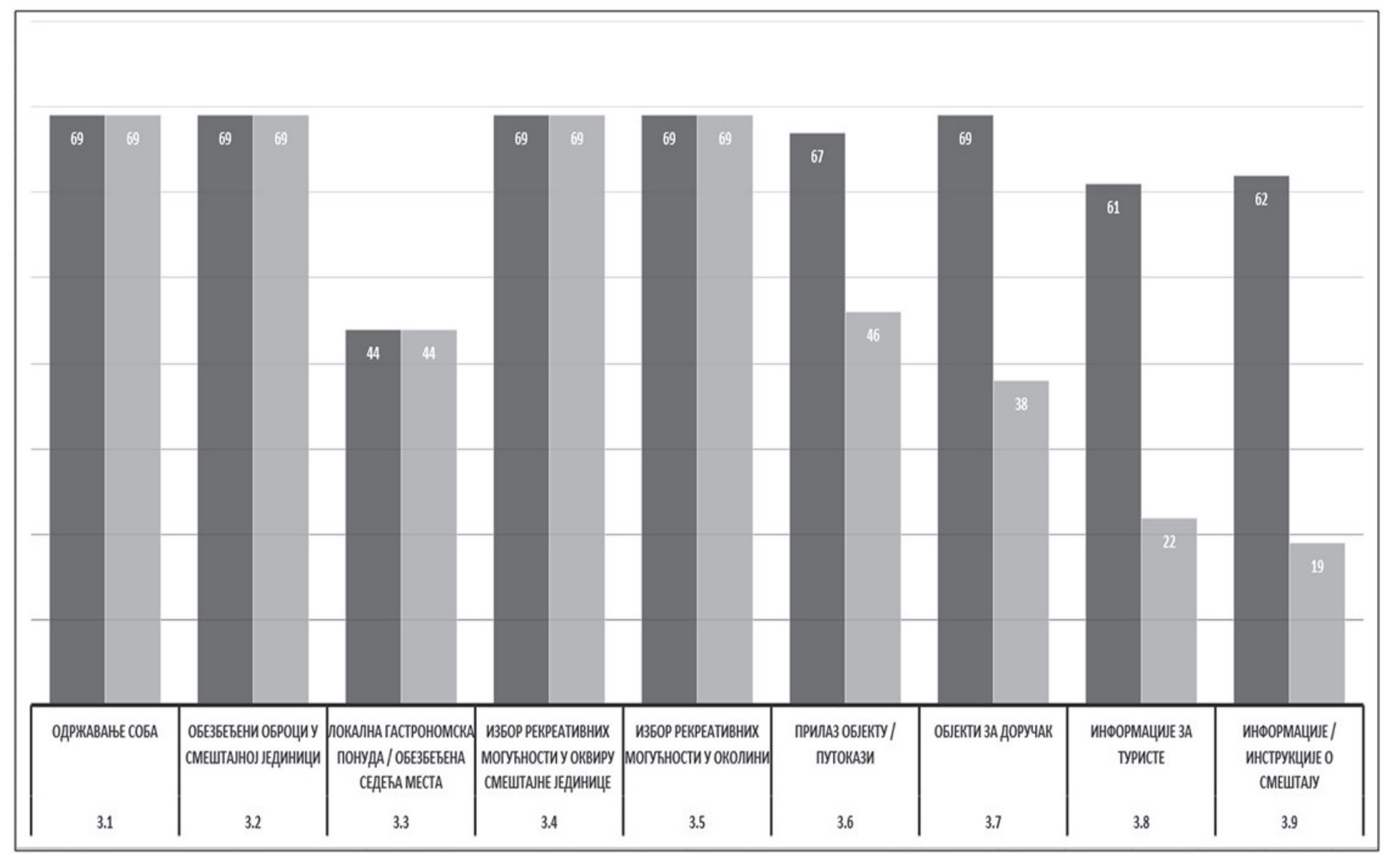

Grafikon 3. Prikaz rezultata ispunjenih standarda prema kriterijumima Bloka 3 (N=69)

Legenda: tamnosivi stubovi - broj ispitanika koji ispunjava uslove za domaće tržište / svetlosivi stubovi - broj ispitanika koji ispunjava uslove i za međunarodno tržište 


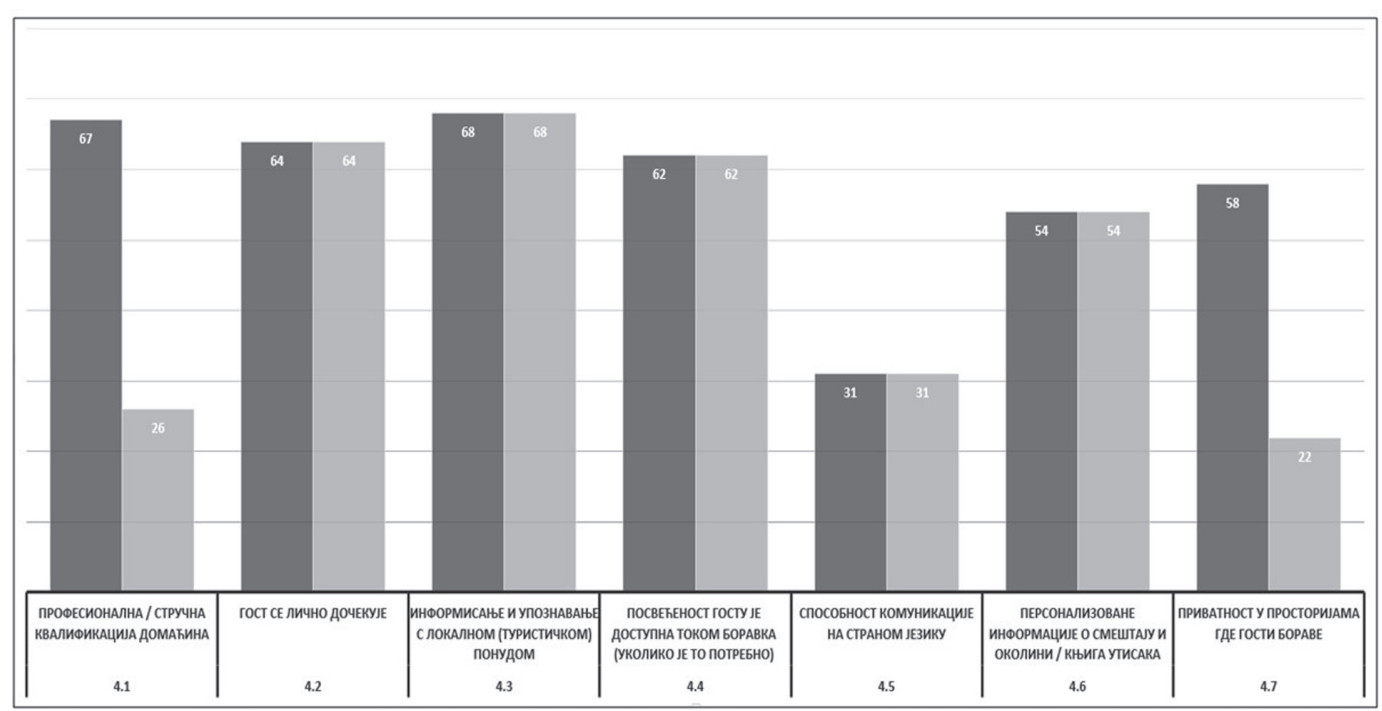

Grafikon 4. Prikaz rezultata ispunjenih standarda prema kriterijumima Bloka 4 (N=69)

Legenda: tamnosivi stubovi - broj ispitanika koji ispunjava uslove za domaće tržište / svetlosivi stubovi - broj ispitanika koji ispunjava uslove i za međunarodno tržište

Rezultati Bloka 4 (Graf. 4) pokazuju veoma visoke vrednosti ( $\mathrm{N} \geq 60)$, prema oba kriterijuma, u kategorijama: ,gost se lično dočekuje” ( $\mathrm{N}=64)$, „informisanje i upozavanje s lokalnom turističkom ponudom” $(\mathrm{N}=68) \mathrm{i}$ „posvećenost gostu je dostupna tokom boravka" ( $\mathrm{N}=62)$. Razlog izjednačenja odgovora je, kao i u ranijim slučajevima, identičnost postavljenih uslova za domaće i međunarodno tržište od strane EuroGites standarda. Prema uslovima za domaće tržište, veoma visoku vrednost beleži i kategorija „profesionalna / stručna kvalifikacija domaćina" ( $\mathrm{N}=67)$, s obzirom na to da nije neophodno imati pohađane dodatne obuke i treninge, kao za međunarodno tržište, gde je vrednost u ovoj kategoriji niska $(\mathrm{N}=26)$. Slično prethodnom, niska vrednost za međunarodno tržište je uočljiva i kod kategorije „privatnost u prostorijama gde gosti borave" ( $\mathrm{N}=22)$, zbog znatno zahtevnijih kriterijuma u odnosu na domaće (sobe, kupatila i druge prostorije su namenjene isključivo gostima). S obzirom da dobijeni rezultati pokazuju da posvećenost gostu, privatnost $i$ ambijent $u$ agroturističkim smeštajnim jedinica- ma u većoj meri zadovolja kriterijume prema domaćim, a u manjoj meri prema međunarodnim standardima (u dva od sedam slučajeva), pothipoteza H1d se delimično usvaja (dva od sedam slučajeva).

U grafikonu koji prikazuje rezultate Bloka 5 može se zaključiti da su izuzetno visoke vrednosti, prema oba kriterijuma, uočljive kod kategorija: „kontrola adekvatnosti tehničke i druge opreme” (N=69), „zaštita od požara i drugih nezgoda” (N=68) i „cenovnik izložen na vidljivom mestu” ( $\mathrm{N}=67)$. Izuzetno visoke vrednosti prema uslovima za domaće tržište beleže i kategorije: „zdravstveni uslovi” ( $\mathrm{N=67),} \mathrm{„garancije}$ o tačnim informacijama pre rezervacije” $(\mathrm{N}=69)$ i „zaštita potrošača" $(\mathrm{N}=64)$. Interesantno je spomenuti da se upravo kod ove tri kategorije javljaju niski pokazatelji kada su u pitanju uslovi za međunarodno tržište. Tako kategorije: „zdravstevni uslovi” ( $\mathrm{N}=24)$ i „Zaštita potrošača” $(\mathrm{N}=21)$, pokazuju niske vrednosti, a kategorija „garancije o tačnim informacijama pre rezervacije" $(\mathrm{N}=14)$ beleži veoma nisku vrednost. Ova pojava se obajšnjava razlogom obimnijih i

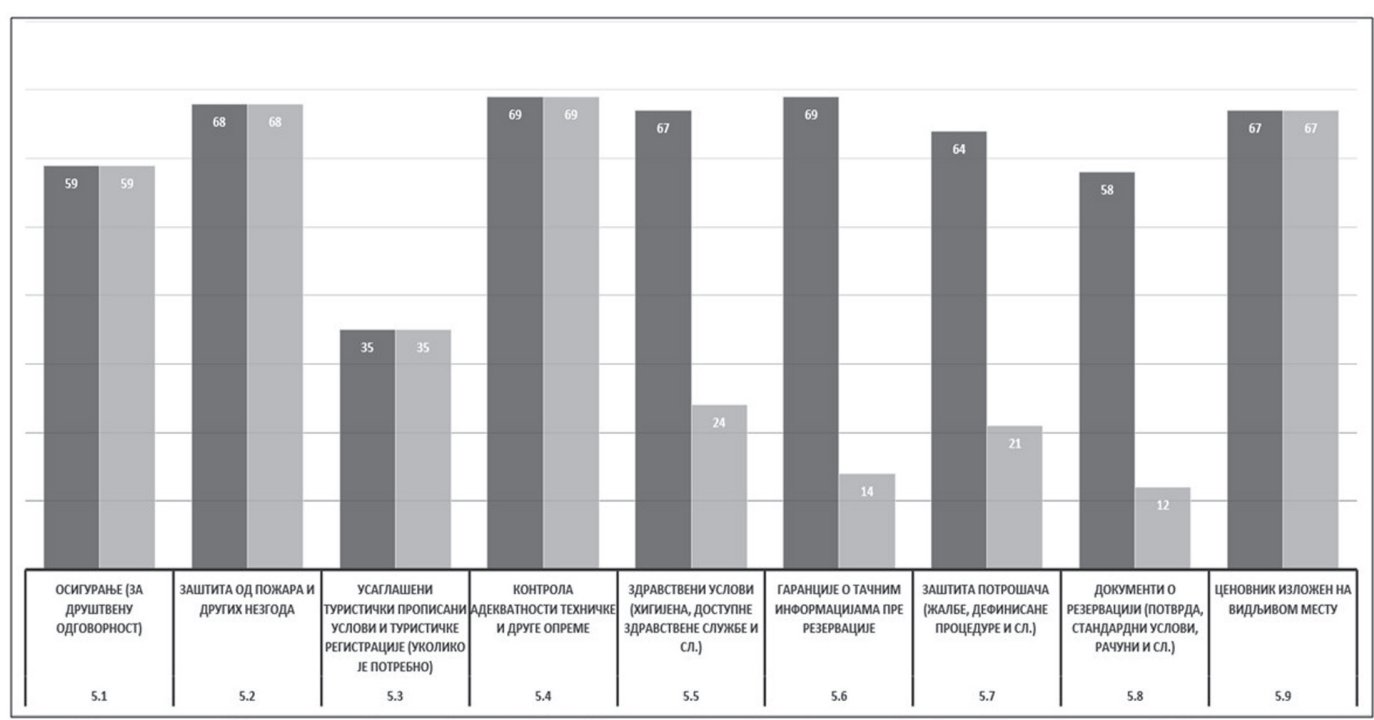

Grafikon 5. Prikaz rezultata ispunjenih standarda prema kriterijumima Bloka 5 (N=69)

Legenda: tamnosivi stubovi - broj ispitanika koji ispunjava uslove za domaće tržište / svetlosivi stubovi - broj ispitanika koji ispunjava uslove i za međunarodno tržište 
rigoroznijih uslova i garancija koje moraju ispunjavati prema ovom kriterijumu (npr. detaljne informacije o zdravstvenim službama u krugu od 15 minuta vožnje, dostupne na zahtev prilikom rezervacije i u potpunosti dostupne u smeštaju tokom boravka, kao i garancije trećeg lica o tačnim informacijama pre rezervacije, obavezan upitnik o zadovoljstvu potrošača i sl.). Uz ove kategorije, i kategorija „dokumenti o rezervaciji” $(\mathrm{N}=12)$ pokazuje veoma nisku vrednost za međunarodno tržište, što je ujedno i najniža vrednost u posmatranim blokovima. Ovakav rezultat se objašnjava činjenicom da se uz standardnu rezervaciju, zahteva i dostupna pisana potvrda o rezervaciji, uslovima i detaljima ugovorene usluge, što domaće tržište, po ovom kriterijumu, ne zahteva. Dobijeni rezultati delimično potvrđuju pothipotezu H1e, s obzirom da bezbednost u agroturističkim smeštajnim jedinicama delimično u istoj, a delimično i u većoj meri zadovolja kriterijume prema domaćim nego prema međunarodnim standardima (četiri od devet slučajeva).

\section{ZAKLJUČAK}

Posmatrajući sveobuhvatnu situaciju, može se delimično potvrditi početna hipoteza u ovom segmentu rada, da će vrednosti za domaće tržište biti viši u odnosu na međunarodne, zbog zahtevnijih kriterijuma, odnosno uslova koji su njima propisani ili će biti identične prema oba kriterijuma. Takođe, na osnovu rezultata, može se izneti par generalnih zaključaka o kvalitetu agroturizma u Vojvodini, koji se odnose na dobijene najviše i najniže (ekstremne) vrednosti u svih pet blokova. Kvalitet agroturizma u Vojvodini je merljiv pomoću poređenja ispunjenosti uslova na domaćem i na međunarodnom nivou, čime se četvrta hipoteza $(\mathrm{H} 1)$ delimično usvaja (+/-). S obzirom da su pothipoteze u svim slučajevima delimično potvrđene, konkretniji zaključci glase ovako:

1. Pothipoteza H1a je delimično potvrđena (+/-), zato što opremljenost agroturističkih smeštajnih jedinica u određenoj meri više zadovolja kriterijume prema domaćim nego prema međunarodnim (devet kriterijuma), a u određenoj meri podjednako zadovolja oba kriterijuma (10 kriterijuma).

2. Pothipoteza H1b je delimično potvrđena (+/-), donošenjem zaključka da okruženje agroturističkih smeštajnih jedinica u određenoj meri više zadovolja kriterijume prema domaćim nego prema međunarodnim (pet kriterijuma), a u određenoj meri podjednako zadovolja oba kriterijuma (četiri kriterijuma).

3. Pothipoteza H1c je delimično potvrđena (+/-), jer usluge $\mathrm{u}$ agroturističkim smeštajnim jedinicama $\mathrm{u}$ određenoj meri više zadovoljaju kriterijume prema domaćim nego prema međunarodnim (četiri kriterijuma), a u određenoj meri podjednako zadovolja oba kriterijuma (pet kriterijuma).

4. Pothipoteza H1d je delimično potvrđena (+/-), zato što posvećenost gostu, privatnost $\mathrm{i}$ ambijent $\mathrm{u}$ agroturističkim smeštajnim jedinicama u određenoj meri više zadovolja kriterijume prema domaćim nego prema međunarodnim (dva kriterijuma), a u određenoj meri podjednako zadovolja oba kriterijuma (pet kriterijuma).

5. Pothipoteza H1e je delimično potvrđena (+/-), jer bezbednost $u$ agroturističkim smeštajnim jedinicama u određenoj meri više zadovolja kriterijume prema domaćim nego prema međunarodnim (četiri kriterijuma), a u određenoj meri podjednako zadovolja oba kriterijuma (pet kriterijuma).

$\mathrm{Na}$ osnovu svega navedenog, može se zaključiti da segmenti kvaliteta u agroturizmu čine važnu osnovu u planiranju i strateškim ciljevima uspešnog privređivanja u ovoj oblasti. Takođe, naglašava se zadovoljenje potreba i motiva savremenog stanovništva za povratak prirodnoj i nezagađenoj sredini. U ovakvoj tendenciji, agroturizam može zauzeti značajan tržišni segment, a poštujući pravila održivog razvoja, i uz negovanje lokalne tradicije i kulture, ovaj vid turizma postaje jedan od strateški najefikasnijih načina budućeg razvoja ruralnih područja.

\section{LITERATURA}

Adams, B.B. (2008). The new agritourism. Hosting community and tourists on your farm. Auburn: New World Publishing.

Babbie, E. (1986). The Practice of Social Research. Belmont: Wadsworth.

Buselić, M., Kersan-Škabić, I., \& Afrić-Rakitovac, K. (2008). Clusters and Rural Tourism. In: $27^{\text {th }}$ International Conference on Organizational Science Development - Knowledge for Sustainable Development, April 19-21. Portorož: University of Primorska, Faculty of Tourism Studies.

Caprarescu, G., Stancu, D.G., \& Aron, G. (2013). Quality by Keeping the Identity or How to Obtain Competitive Advantage in Romanian Rural Tourism. International Journal of Academic Research in Economics and Management Sciences, 2 (1), 1-5.

EuroGites Federation. (2014). Quality standards. Preuzeto 11. maja 2014. sa http://quality.eurogites.org

EuroGites Federation. (2014). General information and topics. Preuzeto 22. avgusta 2014. sa http://www.eurogites. org

George, E.W., Mair, H., \& Reid, D.G. (2009). Rural Tourism Development: Localism and Cultural Change, Bristol: Channel View Publications.

Gherasim, D. (2012). Rural Tourism in Romania. Economy Transdisciplinarity Cognition, XV (1), 279-283.

Hall, D., \& Richards, G. (2000). Tourism and Sustainable Community Development. Oxon: Routledge.

Hall, D.R., Roberts, L., \& Mitchell, M. (2003). New Directions in Rural Tourism: Local Impacts, Global Trends. Hants: Ashgate Publishing.

Nickerson, N.P., Black, R.J., \& McCool, S.F. (2001). Agritourism: motivations behind farm-ranch business diversification. Journal of Travel Research, 40(1), 19-26. DOI: 10.1177/004728750104000104.

Nilsson, P.A. (2002). Staying on farms - an ideological background. Annals of Tourism Research, 29 (1), 7-24. DOI: 10.1016/S0160-7383(00)00081-5.

Organizacija Istar 21. (2013). Projekat Bogatstvo različitosti. Preuzeto 15. avgusta 2013. sa http://www.istar21.rs/projekti/bogatstvo_razlicitosti/3013-projekat-bogatstvo-razlicitosti.html

Petrović, M.D. (2013). Agroturizam u savremenoj naučnoj literaturi. Agroekonomika, 59-60, 94-113. 
Petrović, M.D. (2014). Kvalitet agroturizma Vojvodine i njegov uticaj na stavove lokalnog stanovništva. Neobjavljena doktorska disertacija. Novi Sad: Univerzitet u Novom Sadu, Prirodno-matematički fakultet, Departman za geografiju, turizam i hotelijerstvo.

Reichel, A., Lowengart, O., \& Milman, A. (2000). Rural tourism in Israel: service quality and orientation. Tourism Management, 21, 451-459. DOI: 10.1016/S0261-5177(99)00099-0

Roberts, L., \& Hall, D. (2001). Rural Tourism and Recreation: Principles to Practice. Wallingford: CABI Publishing.

Sirgy, M.J., \& Cornwell, T. (2001). Further validation of the Sirgy et al.'s measure of community quality of life. Social Indicators Research, 56, 125-143. DOI: 10.1023/A:1012254826324

Sirgy, M.J. (2001). Handbook of Quality-Of-Life research: An ethical marketing perspective. Dordrecht: Kluwer Academic Publisher.
Spanos, K.G., \& Doman, U. (2011). Basic Steps on Rural Tourism Sustainable Development: The Example of Greece. International Journal of Agricultural Travel and Tourism, 2 (1), 1-6.

Stoian, M. (2011a). Comparative Analysis between Tourism and Rural Tourism during Economic Crisis (20082010). Scientific Papers Series Management, Economic Engineering in Agriculture and Rural Development, 11 (3), 221-223.

Stoian, M. (2011b). The Evaluation of Marketing Methods in a Tourism Association from Romania. Annals of the University of Petroşani, Economics, 11(1), 253-260.

Sznajder, M., Przezborska, L., \& Scrimgeour, F. (2009). Agritourism. Wallingford: CABI Publishing.

\section{THE USE OF EUROGITES STANDARD IN QUALITY ASSESSMENT OF AGRI-TOURISM SERVICES}

\begin{abstract}
:
The paper presents conceptual terms of agritourism through connection with the service quality criteria. Based on best practices and experiences of some European countries, the European Federation of Farm and Village Tourism (EuroGites) has established common quality assessment standards for accommodation units in rural areas. Those criteria are grouped into five clusters (blocks): equipment, surroundings, services at the accommodation facility and its surroundings, non-material aspects and security. The principal aim of the paper is to perform comparison between minimum requirements for international and domestic markets using EuroGites methodological instrument, through assessment of agritourism quality segments in the selected village settlements on the territory of Vojvodina Province (Serbia). The main hypothesis was based on the estimation that the quality of agritourism in Vojvodina Province is measurable by comparing the EUroGites criteria fulfillment at domestic and international level. The results show that the three sub-hypotheses have been confirmed, while two have been rejected. The research findings represent a useful tool for obtaining information on numerous aspects of quality in agritourism and they can be used in various areas of services quality research with slight modifications.
\end{abstract}

\section{Key words:}

agritourism, EuroGites, criteria clusters, quality segments, Vojvodina Province (Serbia). 